Federal Reserve Bank of Minneapolis

Research Department

\title{
Prosperity and Depression: 2002 Richard T. Ely Lecture
}

\author{
Edward C. Prescott \\ Working Paper 618
}

January 2002

\begin{abstract}
*University of Minnesota and Federal Reserve Bank of Minneapolis. I thank my colleagues at the University of Minnesota and the Federal Reserve Bank of Minneapolis for helpful discussions and comments. In particular, I thank Tim Kehoe and Ellen McGrattan for their help. I also thank Martin Weale and Franck Portier for providing some British and French tax information used in this lecture. Thanks also go to Sami Alpanda and James MacGee for research assistance and helpful discussions. This lecture draws heavily on collaborative research with Fumio Hayashi. I thank the Economic and Social Research Institute, Cabinet Office, Government of Japan and the U.S. National Science Foundation for financial support. The views expressed herein are those of the author and not necessarily those of the Federal Reserve Bank of Minneapolis or the Federal Reserve System.
\end{abstract}


Prosperity and depression are relative concepts. Today both France and Japan are depressed relative to the United States; equivalently, the United States is prosperous relative to these countries. I say these countries are depressed relative to the United States because their output per working-age person is 30 percent less than the U.S. level. An interesting and important policy question is, Why are these countries depressed? The answers for these two countries turn out to be very different.

The United States is prosperous relative to France because the U.S. intratemporal tax wedge that distorts the tradeoff between consumption and leisure is much smaller than the French wedge. I will show that if France modified its intratemporal tax wedge so that its value was the same as the U.S. value, French welfare in consumption equivalents would increase by 19 percent. Consumption would have to increase by 19 percent now and in all future periods to achieve as large a welfare gain as that resulting from this tax reform.

The United States is prosperous relative to Japan because production efficiency is higher in the United States. In the United States, total factor productivity is approximately 20 percent higher than in Japan. If Japan suddenly became as efficient in production as the United States, its welfare gain in consumption equivalents would be 39 percent.

Equally interesting and important are big changes over time in relative output (per working-age person) across countries. Why are New Zealand's and Switzerland's economies depressed by over 30 percent relative to their 1970 trend-corrected levels? Both of these countries have small populations, but depressions are not restricted to small countries. Japan, with its 125 million people, is now depressed by 20 percent relative to its 1991 trend-corrected level. On the prosperity side, why are Ireland and South Korea so prosperous now relative to their 1970 trendcorrected levels? 
This lecture is concerned primarily with big international differences among relatively rich industrial countries and changes in these differences over time. The countries that receive primary attention all have market economies and healthy, well-educated populations.

In the countries considered, the variations in aggregate output per working-age person are large, and reasonably good measures of the factor inputs are available. This permits, in many cases, the identification of the change in policy or the difference in policy that gave rise to prosperity or depression. This is in contrast to business cycle theory, which provides little guidance to policy except for the important policy implication that a stabilization effort will have either no effect or a perverse effect. The output variations studied and analyzed in this lecture are big: an order of magnitude larger than the much-studied business cycle fluctuations. The variations studied, however, are an order of magnitude smaller than the much-studied differences between the richest and poorest countries.

Surprisingly, only recently have depressions been systematically studied from the perspective of growth theory, which is the theory used to study not only secular growth but also business cycle fluctuations. Harold L. Cole and Lee E. Ohanian (1999) break the taboo against studying depressions from this perspective. The January 2002 issue of The Review of Economic Dynamics, edited by Timothy J. Kehoe and Edward C. Prescott (2002), examines a number of the great depressions of the twentieth century from the perspective of growth theory. This lecture draws heavily on these studies.

In the above discussion, the intertemporal comparisons have no meaning until trend growth is defined. Trend growth is the result of growth in the stock of world knowledge that can be accessed at modest cost and that enhances production possibilities. Trend growth is important for understanding why countries are so much richer today on average than they were 50 or 100 
years ago. It is not important for understanding relative levels across countries and changes in relative levels across countries over time, which are the topics of this lecture.

What rates should be used to measure trend growth? I assume that the stock of world knowledge useful in production grows smoothly over time. In this lecture, I will use a 2 percent constant annual growth rate throughout the twentieth century. This is the average growth rate of output per working-age person in the United State in the twentieth century. Figure 1 shows that the only large deviations of U.S. output per working-age person in the twentieth century from a 2 percent trend occur during the Great Depression of the 1930s and the World War II output boom. I see the use of a 2 percent trend growth rate as a much better procedure than ignoring it completely in the tradition of NBER business cycle analyses.

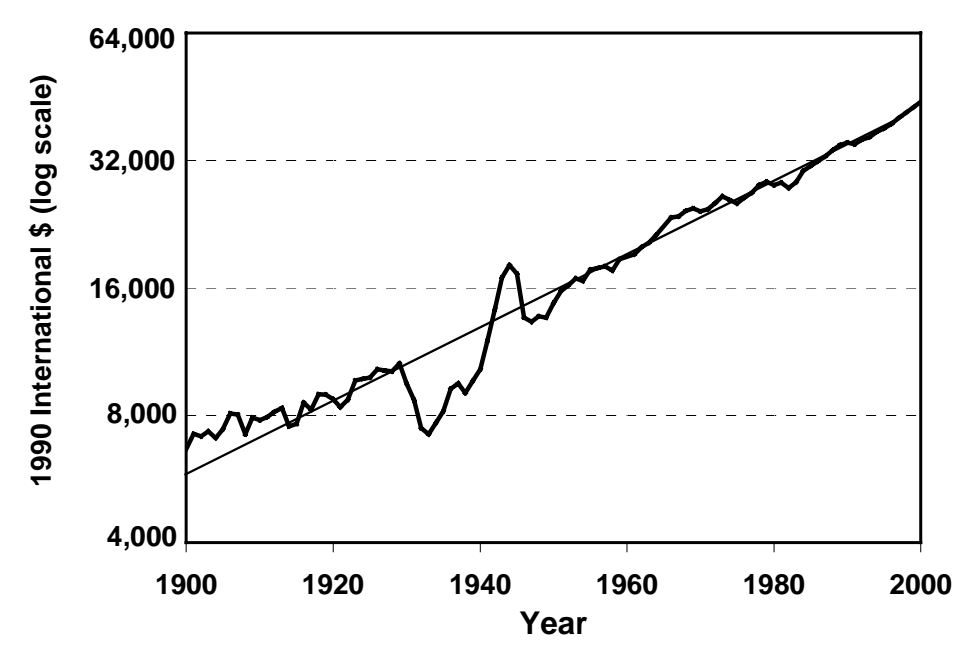

Figure. 1: U.S. GDP per Person Aged 15-64

Again, why are New Zealand and Switzerland now depressed by 30 percent relative to their 1970 trend-corrected levels, a fact depicted in Figure 2? Mexico is the only other member of the Organization for Economic Cooperation and Development (OCED) that is depressed to a significant extent relative to its 1970 trend level. Japan is currently depressed relative to its 1991 
level, but not relative to its 1970 level. Ireland and Korea are the two OECD members that currently are significantly more prosperous relative to their trend-corrected 1970 levels. Ireland is now 60 percent above its 1970 level, and Korea is 160 percent above its 1970 level.

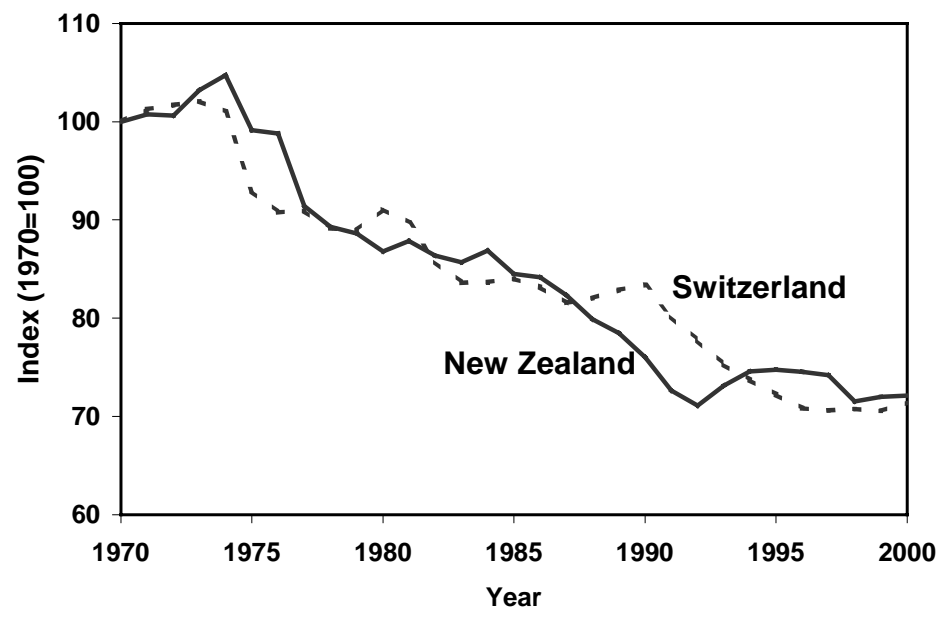

Figure 2: Two Contemporary Depressions

Table 1 shows that Belgium, France, Germany, Italy, and Netherlands prospered in the postwar period relative to their prewar trends. Why did these countries all increase their trendcorrected productivity levels by 80 percent relative to their pre-World War II levels? I think that these original European Union countries are prosperous relative to their prewar trend-corrected levels because an economic policy change resulted in productivity increasing to 180 percent of its pre-World War II trend level. In this lecture, I will discuss what I see as the key change in policy that may have given rise to this increase. 


\section{Table 1}

\section{Detrended Labor Productivity (1913=100) Original EU Countries}

\begin{tabular}{cc}
\hline Year & EU \\
\hline 1913 & 100 \\
1929 & 102 \\
1938 & 96 \\
1950 & 75 \\
1973 & 162 \\
1992 & 181 \\
\hline
\end{tabular}

Source: Angus Maddison (1995, Table J-5; p. 245). The EU countries are Belgium, France, Germany, Italy, and Netherlands.

The theoretical framework used in this lecture is the growth model. The key elements of the theory are the aggregate production function of the stand-in firm and the utility function of the stand-in household. The technology side specifies people's ability to substitute, whereas the preference side describes people's willingness to substitute. With price-taking behavior, the ability and willingness to substitute are equated.

In this lecture, I will devote particular attention to Japan, an interesting country from the perspective of the growth theory given its growth miracle in the 1955-72 period and its current depressed state. Fumio Hayashi and Prescott (2002) have recently studied Japan to understand why its economy is now depressed nearly 20 percent relative to its level 10 years ago. The Japanese people probably want to know what set of policy reforms will lead to prosperity. 


\section{The Importance of National Income and Product Accounts}

The connection between Richard T. Ely and this lecture is through students of his students. Wesley Mitchell may well be Ely's greatest student. Mitchell, in turn, had at least two truly great students. One was Irving Fisher, who was one of the earliest to recognize that the principles applicable to static economic analyses are equally applicable to dynamic economic analyses once goods are indexed by date. This is the dynamic economic theory used in this lecture. Another of Mitchell's great students was Simon S. Kuznets, whose statistical work measuring the performance of national economies is the genesis of the growth model. Kuznets $(1926,1937,1941)$ measured gross national product and its investment and consumption subcomponents. He and his students measured categories of claims against this product. ${ }^{1}$ Kuznets came up with a measure of aggregate capital inputs. Others, in particular, his student John H. Kendrick (1956), came up with measures of the labor input and estimates of productivity.

The best accounting system from the perspective of growth theory, however, is the original modern U.S. national income and product accounts system, the conceptual basis of which is important due to George Jaszi (Richard Ruggles, 1983, p. 23). This system is used by Hayashi and Prescott (2002) in their study of the Japanese economy in the 1990s and in this lecture for the 1960-90 period. Gross national product, rather than gross domestic product, is used because GNP is the income of households in the growth model. If a single-sector model is used, growth theory dictates the use of GNP rather than GDP, with net exports and net foreign factor income as part of investment. With the original modern U.S. system, for example, earning on a foreign investment is treated as an export of capital services. With these accounting conventions, saving equals investment and output is the sum of private consumption expenditure, government purchases of goods and services, and investment. 
Inputs and outputs to the market sector measure the performance of the market sector. The performance of the market sector in turn measures the performance of economic policy. Bad performance of the market sector is the result of bad economic policies, where policy is broadly defined to include the regulatory and legal environment as well as tax policies.

U.S. economists are not the only important contributors to the development of the national income and product accounts. British economists developed a good system of national accounts, which is the basis for the UN system used throughout most of the world today. For the conceptual ideas underlying the development of the UN system, Richard Stone (1986) gives credit to Colin Clark (1937). Stone, D. G. Champernowne, and J. E. Meade (1942), however, formalize Clark's ideas and put them into a consistent accounting framework.

\section{The Growth Model and an Accounting Framework}

The national income and product account statistics display certain regularities: the relative constancy of factor income shares, the investment-consumption shares, the fraction of productive time allocated to the market, and the capital/output ratio. These observations along with the secular growth in output per working-age person led to the growth model.

Real business cycle theorists are interested in business cycle fluctuations, and they extended the growth model in two respects: They introduced uncertainty and they made the labor-leisure decision endogenous. They, and I think others in the profession, were surprised to find that the growth model extended in this way displayed the business cycle facts given the behavior of real shocks, that is, the behavior of factors determining the steady state of the deterministic growth model. This was a great success for growth theory, which was designed to account for the growth facts. In this lecture, I use this theory to study periods of prosperity and depression. I use the same model as the one used by the real business cycle theorists except that my model has no un- 
certainty. I focus on relative levels and equilibrium paths, rather than statistical properties of the time series.

Business cycle theorists found that the stand-in household's elasticity of substitution between consumption and leisure must be large if the extended growth model is to display the business cycle facts. I see overwhelming micro evidence that this elasticity is large, though many labor economists disagree. ${ }^{2}$ In this lecture, I will report additional evidence in support of a high value for this substitution. The first category of evidence is the nonconstant growth behavior of the Japanese economy in the 1970-2000 period. The second category of evidence is the differences in market hours per working-age person associated with differences in the intratemporal tax wedge.

Accounting for differences in output levels is closely related to, but differs from, the growth accounting of Robert M. Solow (1957), who developed his accounting procedure before the development of the general equilibrium growth model in which the consumption-investment decision and the labor-leisure decision are endogenous. My model has two central elements. The first is the technology, which consists of an aggregate production function and the capital accumulation equation. The aggregate production function is the stand-in for technology, and there is some well-known aggregation theory behind it (Lionel W. McKenzie, 1981). The second is a utility function for the stand-in household that depends on the path of consumption and leisure. There is some not-so-well-known aggregation theory behind the stand-in household utility function. $^{3}$

The aggregate production function defines the maximum output that can be produced given the quantities of the inputs. With competition, this maximum output is, in fact, the equilibrium output. Further, payments to the factors of production exhaust product. Thus, the aggregate 
production function, along with competitive equilibrium, provides a theory of the income side of the national income and product accounts given the quantities of the factor inputs.

The near constancy of factor income shares across countries and time (Douglas Gollin, forthcoming) leads to the Cobb-Douglas production function:

$$
C_{i t}+X_{i t}=Y_{i t}=\left(A_{i t} \gamma^{t}\right)^{(1-\theta)} K_{i t}^{\theta} H_{i t}^{1-\theta} .
$$

Here $K$ denotes the capital stock in period $t ; H$, aggregate hours worked; $C$, aggregate consumption; and $X$, aggregate investment. The productivity or efficiency parameter $A$ is a country-specific productivity parameter that varies over time and is exogenous to the stand-in firm, but is determined by policies. It measures the efficiency with which inputs are used in producing output. The capital stock depreciates geometrically:

$$
K_{i, t+1}=K_{i t}-\delta K_{i t}+X_{i t} .
$$

The stand-in household's utility function is

$$
\sum_{t=0}^{\infty} \beta^{t} N_{i t}\left[\log c_{i t}+\alpha \log \left(1-h_{i t}\right)\right]
$$

Here $N_{t}$ is the working-age population, $c_{t}=C_{t} / N_{t}$, and $h_{t}=H_{t} / N_{t}$.

Suppose that the working-age population grows at constant rates $N_{t}=N_{0} \eta^{t}$ and that the country-specific productivity parameter $A_{i t}$ remains constant. Then this economy has a unique constant-growth path in which all the quantities per working-age person grow by the factor $\gamma$, except market hours per working-age person $h$, which is constant. This fact motivates the accounting that I adopt.

My level accounting rearranges terms in the production function and takes logarithms to decompose the determinants of output into trend and three factors. The advantage of this decomposition is that each of the three factors leads to the examination of a different set of policies. Using 
lowercase letters to denote the per working-age person value of a variable and taking logarithms,

I write the production function as

$$
\log y_{t}=\gamma t+\log A_{t}+\frac{\theta}{1-\theta} \log \left(k_{t} / y_{t}\right)+\log h_{t} .
$$

This representation provides a decomposition of the log of output into the following four factors:

1. Trend growth $\gamma t$.

2. Productivity factor $\log A_{t}$.

3. Capital factor $\frac{\theta}{1-\theta} \log \left(k_{t} / y_{t}\right)$.

4. Laborfactor $\log h_{t}$.

Along a constant growth path, output per working-age person grows at the trend rate and each of the three other factors remains constant. Shifts in policy change the constant growth values of these factors and, therefore, change the intercept of the constant growth path as well. Constraints imposed upon the way businesses operate, such as a requirement for extra staffing or a restriction on the adoption of a more efficient production technology, will reduce the productivity factor. A change in the tax system that makes consumption more expensive in terms of leisure will reduce the constant growth value of the labor factor. A change in the tax system that taxes capital income at a higher level will reduce the constant growth value of the capital factor. ${ }^{4}$

\section{A. Convergence to the Constant Growth Path}

An essential feature of the constant growth path is that, in the absence of a policy change, the equilibrium converges to a constant growth path. Along a convergence path, the capital and labor factors will not be zero. If the economy is below its constant growth path, the labor input will be high and the capital factor low. Both of these factors converge to their constant growth 
values. As I will discuss, nonconstant growth behavior characterized the Japanese economy throughout the last 40 years of the twentieth century.

In this lecture, I use a trend growth rate of 2 percent per year because this is the secular growth rate of the U.S. economy in the twentieth century, $\gamma=1.02$. A motivation for using the U.S. growth rate is that the United States is large, diverse, and politically stable, and it was the industrial leader throughout the twentieth century. Perhaps in the twenty-first century, the European Union will become the industrial leader, and it will be appropriate to define the trend growth rate relative to that economy rather than to the U.S. economy. Perhaps the trend growth rate will increase; perhaps it will decrease. What will happen to trend growth $\gamma$ is an interesting question, but not the one addressed in this lecture.

\section{B. Some Level Accounting}

France, Japan, and the United Kingdom are currently depressed relative to the United States by about 30 percent. The accounting for these depressions is in Table 2, where for each factor the U.S. level has been normalized to 1 . The table shows that most of the French depression is due to the depressed labor factor, while most of the Japanese depression is due to a depressed productivity factor. 
Table 2

1998 Level Accounting Relative to the United States

\begin{tabular}{lcccc}
\hline & GDP & $\begin{array}{c}\text { Productivity } \\
\text { factor }\end{array}$ & $\begin{array}{c}\text { Capital } \\
\text { factor }\end{array}$ & $\begin{array}{c}\text { Labor } \\
\text { factor }\end{array}$ \\
\hline France & $-31 \%$ & $6 \%$ & $1 \%$ & $-37 \%$ \\
Japan & $-31 \%$ & $-33 \%$ & $3 \%$ & $-1 \%$ \\
United Kingdom & $-41 \%$ & $-29 \%$ & $2 \%$ & $-13 \%$ \\
\hline
\end{tabular}

Source: GDP series are from OECD (2001). The series used was GDP at the prices and PPPs of 1995. The capital/output ratios are from OECD (1997) except Japan, which is from the Japanese SNA. The capital/output ratios are for 1996, which is the latest available year. The labor input was obtained by multiplying the "Average actual annual hours worked per person in employment" and "Total Employment" series obtained from the Labor Market Statistics of the OECD Corporate Data Environment, which is available at http://www1.oecd.org/scripts/cde.

\section{Introducing Taxes into the Model}

Taxes affect the constant growth path of my model. I introduce three proportional taxes: a consumption tax, $\tau_{c t}$; a labor income tax, $\tau_{h t}$; and a capital income tax, $\tau_{k t}$. All receipts are distributed lump-sum back to the stand-in household. This is not to say that there is no public consumption. Rather, I combine public consumption with private consumption. Implicitly, I am assuming that public schools are a good substitute for private schools, publicly provided police protection a good substitute for privately provided security protection, publicly provided roads a good substitute for tolls roads, and so on.

If some small fraction of GNP is allocated to pure public goods, the conclusions of this analysis are unchanged. This assumption that not all public consumption is a good substitute for private consumption would not be reasonable in a model economy with large military expendi- 
tures, as was the case for Germany in the 1936-45 period and the United States beginning in the 1942-45 wartime period.

Because I want to identify the role of consumption tax in the consumption-leisure decision, I use the price received by the producer for the value of the consumption good. National income and product accounting uses the price paid by the household for the value of consumption goods and services. The intertemporal budget constraint is

$$
\sum_{t=0}^{\infty} p_{t} N_{t}\left[\left(1+\tau_{c t}\right) c_{t}+x_{t}-\left(1-\tau_{h t}\right) w_{t} h_{t}-r_{t} k_{t}-\tau_{k t}\left(r_{t}-\delta\right) k_{t}+T_{t}\right] \leq 0
$$

Here the $p_{t}$ are the intertemporal prices faced by the household; $r_{t}$, the rental prices of capital; $w_{t}$, the wage rate; and $T_{t}$, the transfer payment.

\section{A. The Intertemporal Tax Wedge}

In fact, the tax system is more complicated than this, with property taxes, investment tax credits, useful lives of capital equipment differing from book value lives, and so on. These features of the tax system affect the capital factor, but the capital factor differs little across countries. ${ }^{5}$ From the perspective of capital accumulation, tax systems in the major OECD countries are roughly equivalent. For the tax system considered, the intertemporal tax wedge is

$$
r_{t}=i_{t} /\left(1-\tau_{k}\right)+\delta
$$

\section{B. The Intratemporal Tax Wedge}

Equating the marginal rate of substitution between leisure and consumption to their price in the household's budget constraint yields the equilibrium condition

$$
1-h_{t}=\frac{\left(1+\tau_{c t}\right)}{\left(1-\tau_{h t}\right)} \frac{\alpha c_{t}}{w_{t}}
$$


where $w$ is the wage rate and the tax rates are marginal rates. With convex tax schedules, the differences between the marginal tax rate on labor income times labor income and labor income tax paid is treated as a transfer to the household. A useful equilibrium relation for $h$ is

$$
h=\left[1+\frac{\alpha(c / y)}{(1-\theta)} \frac{1+\tau_{c}}{1-\tau_{h}}\right]^{-1} .
$$

This relation is useful because constant growth $c / y$ does not depend upon either $\tau_{c}$ or $\tau_{h}$. I define the intratemporal tax wedge as

$$
\frac{1+\tau_{c}}{1-\tau_{h}}
$$

This factor matters for labor supply in the following sense. The equilibrium is a function of the product of $\alpha$ and this tax wedge, and not of $\alpha, \tau_{c}$, or $\tau_{h}$ separately.

The assumption that the tax revenues are given back to households either as transfers or as goods and services matters. If these revenues are used for some public good or are squandered, private consumption will fall and the tax wedge will have little consequence for labor

supply. ${ }^{6}$ If, as I assume, it is used to finance substitutes for private consumption, such as highways, public schools, health care, parks, and police protection, then the $c_{t} / w_{t}$ factor will not change when the intratemporal tax factor changes. In this case, changes in this tax factor will have large consequences for labor supply.

\section{The Capital Factor}

The capital factor is not an important factor in accounting for differences in incomes across the OECD countries. Table 3 reports the capital/output ratios for all OECD countries for which data are available in the most recent OECD (1997) data set. ${ }^{7}$ The capital stock is the tangible private capital stock including the capital stock of quasi-corporations, which are govern- 
ment enterprises in the nomenclature of the U.S. national income and product accounts. The ratio is between 2.2 and 2.7 with the smallest value being for France. The similarities of investment shares of product and growth rates suggest that the number for France is higher than 2.2. Perhaps different accounting conventions are followed in France with respect to the useful lives of different types of capital. The low 2.3 number for the United States is reasonable given the lower U.S. savings rate and higher U.S. population growth rate.

Table 3

1990 Capital/Output Ratios

\begin{tabular}{lc}
\hline Country & K/Y \\
\hline Australia & 2.4 \\
Denmark & 2.7 \\
Finland & 2.7 \\
France & 2.2 \\
Germany & 2.7 \\
Italy & 2.6 \\
Japan & 2.5 \\
Norway & 2.6 \\
United Kingdom & 2.6 \\
United States & 2.3 \\
\hline
\end{tabular}

Source: Nominal capital stock numbers are from OECD (1997) except Japan, which is from the Japanese SNA and is for 1998. The series used is net stock of fixed capital. Government capital is not included in this number. Nominal GDP numbers are from OECD (2001). 
Using a capital income share parameter of 0.3 , which is the approximate capital share of total product for all of the countries (Gollin, forthcoming), the capital factor contributes at most 8 percent to the differences in income between any of these countries.

Raphael Bergoeing et al. (2002) find that the Chilean and Mexican economies in the late 1980s are exceptions to the capital factor being unimportant in accounting for differences in income levels. At that time, some changes led to a higher constant growth capital/output ratio. In the case of Chile, Bergoeing et al. (2002) subsequently found that a cut in the corporate income tax rate from 46 percent to 10 percent accounts for the change. In the case of Mexico, there was no explicit change in the tax code. However, the banking system was nationalized at that time, with most loans being made to state enterprises and firms that were effectively bankrupt, so there could have been a change in the effective tax rate on capital income.

\section{The Labor Factor}

The labor factor is important in accounting for depressions. In some cases, a low labor factor can be accounted for by a high marginal tax rate on labor income and consumption. In other cases, as I will show, other policies that distort labor markets must be the cause of the low labor input. The labor input might also be low because the economy's capital stock is above its constant growth path associated with its current policies. If the economy were near its constant growth path and an unexpected change in policy lowered the constant growth path, the labor input would fall below its new constant growth level and then converge up to this new level.

\section{A. The Cause of the Current French Depression: Taxes}

France is currently depressed by about 30 percent relative to the United States with the labor factor accounting for nearly all of the depression. The capital factor and the productivity factor are essentially equal in the two countries, whereas market time is about 30 percent lower in 
France than it is in the United States. Some suggest that the French can make more productive use of their nonmarket time. But why did they work 10 percent more than the U.S. workers in the 1970s? My analysis finds that French and U.S. preferences are similar and that the large difference in labor supply is the result of differences in policy that result in different intratemporal tax wedges.

For France and the United Kingdom, I now determine how much of the difference in labor supply is due to differences in the intertemporal tax wedge. I need an estimate of the consumption tax rate $\tau_{c}$ and the marginal tax rate on labor income $\tau_{h}$ to calculate the intratemporal tax wedge. These tax rates are estimated as follows. ${ }^{8}$

My estimate of the consumption tax rate is the ratio of indirect taxes divided by private consumption net of indirect taxes. ${ }^{9}$ The motivation for this procedure is as follows. Most of indirect taxes, including sales and value-added taxes, are consumption taxes. A property tax on an owner-occupied house is equivalent to a consumption tax on the consumption services that the house provides to the owner. The small part of indirect taxes on investment and public consumption will be ignored. Given that the same procedure is used for each country, this will not affect my conclusions.

The procedure for calculating the marginal tax rate on labor income is more complicated. First I calculate the average social security tax rate on labor income by dividing social security taxes by an estimate of labor income. The estimate of labor income is the labor share parameter times output, where output is GDP less indirect taxes. The labor share parameter used is 0.70 .

Next I calculate the average tax rate on factor income and assume that the average tax rate on factor income is equal to the average tax rate on labor income. The estimated average tax rates on labor income are direct taxes paid by households divided by GDP less the sum of indi- 
rect taxes and depreciation. Given the progressivity of the tax systems, these average tax rates are multiplied by 1.6 to obtain estimates of marginal income tax rates on labor income not including the social security tax.

A summary of the tax rates for France, the United Kingdom, and the United States are reported in Table 4, which shows that the intratemporal tax wedge is large. In France, a worker who works more and produces an additional unit of the consumption good gets to consume less than 0.40 units of consumption. In the United States, the additional consumption is 0.60 units, and in the United Kingdom, the additional consumption is 0.54 units.

Table 4

Current Intratemporal Tax Wedge for France, the United Kingdom, and the United States

\begin{tabular}{lccc}
\hline & France & $\begin{array}{c}\text { United } \\
\text { Kingdom }\end{array}$ & $\begin{array}{c}\text { United } \\
\text { States }\end{array}$ \\
\hline$\tau_{c}$ & .33 & .26 & .13 \\
$\tau_{h}$ & .49 & .31 & .32 \\
$\quad$ social security tax & .33 & .10 & .12 \\
$\quad$ marginal income tax & .15 & .21 & .20 \\
$\quad$ & & & \\
Intratemporal tax wedge & 2.58 & 1.82 & 1.46 \\
& & & \\
Hours $h$ & .183 & .235 & .268 \\
Predicted $h$ & .189 & .250 & .268 \\
\hline
\end{tabular}

Source: United Nations (2000).

These marginal tax rates are roughly what are obtained with a typical household. In the United States in 1997, the average marginal federal income tax rate of working-age people was 
19.5 percent. ${ }^{10}$ This number was computed as follows. The Internal Revenue Service reports the number of single returns and the number of joint returns by marginal tax rates. I doubly weighted the number of joint returns in the calculation of this average marginal tax rate because most of these households had two working-age members. Some labor income is in the form of untaxed fringe benefits, which lowers the 19.5 percent number. However, state and city income taxes work in the opposite direction. These considerations led me to the conclusion that the 20 percent for the marginal tax rate is a reasonable number.

\section{B. Major Findings}

1. France is depressed by 30 percent relative to the United States because the French labor factor is 30 percent lower. The difference in the labor factors is due to differences in the tax systems.

2. The welfare gain in consumption equivalents of France reforming its tax system so that its intertemporal tax wedge is the same as the U.S. tax wedge is 19 percent.

I find it remarkable that virtually all of the large difference in labor supply between France and the United States is due to differences in tax systems. I expected institutional constraints on the operation of labor markets and the nature of the unemployment benefit system to be more important. I was surprised that the welfare gain from reducing the intratemporal tax wedge is so large. Welfare gains associated with reforming tax systems are typically closer to 2 percent than to 20 percent. Table 4 shows that the intratemporal tax wedge for the United Kingdom is between that of France and the United States, as is its labor factor.

Was the U.S. boom of the 1980s the result of lowering marginal tax rates on labor income in the 1986 Tax Reform Act? The increase in the labor factor in that decade suggests that it might 
be. Was the large decline in the labor input in France in the 1929-38 period (Beaudry and Portier, 2002) the result of an increase in the marginal tax rates on labor income? These are interesting questions.

\section{Labor Market Distortions and the Interwar German, U.K., and U.S Depressions}

Taxes are not the only reason that the labor factors differ. An example of this is the interwar U.K. depression. As reported by Cole and Ohanian (2002, p. 42), this depression began in 1920 and continued into the late 1930s. They also report that between 1913 and 1929, real output per adult fell by 1 percent in the United Kingdom while it rose by 30 percent in the rest of the world. The labor factor accounts in large part for the United Kingdom being depressed in 1929 by about 30 percent relative to its trend-corrected pre-World War I level.

The Cole and Ohanian (2002) analysis finds that government social policies were undoubtedly the cause of the interwar period depression in the United Kingdom. There were high levels of unemployment benefits and housing subsidies in conjunction with the need for labor to move from the depressed northwest to southern England where the jobs were more plentiful. Cole and Ohanian (2002) write in their conclusion, "Benefits were particularly attractive to workers in export industries, because they faced high costs of leaving depressed regions due to local housing subsidy policies."

As shown by Lars Ljungqvist and Thomas J. Sargent (1998), some social policies that work well in times when there is little need to reallocate labor work poorly when there is the need for large reallocations as there was in the United Kingdom in the interwar period.

The interwar German depression is another dramatic example of labor market policies giving rise to a depression. Fisher and Hornstein (2002) find a 10.9 percent increase in the trendcorrected real wage associated with the 30 percent fall in output and employment. Once the real 
wage was again at trend, the German economy quickly recovered and returned to trend. Large increases in public consumption did not lead to the German recovery; most of the recover occurred before the increase in government expenditures.

Cole and Ohanian (1999) find that the U.S. economy did not recover in the 1935-39 period from the Great Depression because the labor factor did not recover. Cole and Ohanian (2002) conclude that this failure was the result of New Deal policies that cartelized heavy industries. Wages in this sector were high relative to other sectors and became even higher relative to other sectors as the result of New Deal policies. A consequence of this is that relative employment in this sector declined. Political support for this cartelization declined in 1939 as reflected in the shift of the Roosevelt coalition. Subsequent to this shift, the labor factor increased and the U.S. economy returned to its 1929 trend. The return to trend was prior to any large increase in military expenditures.

\section{The Productivity Factor}

The productivity factor is the most important factor in accounting for prosperity and depressions. This is consistent with what development economists (Hall and Jones, 1999; Klenow and Rodriguez-Clare, 1997) have found, namely, that international income differences are in large part accounted for by differences in total factor productivity, even after correcting for the quality of the labor input. ${ }^{11}$ It is consistent with the findings of real business cycle theorists that in the postwar period, productivity shocks are the major contributor to business cycle fluctuations.

The productivity factor is the major one in accounting for the Chilean depression that began in 1980, including the spectacular recovery (Bergoeing et al. 2002); in accounting for the Mexican depression that began in 1982 and continues (Bergoeing et al. 2002); in accounting for 
the Argentine depression that began in the early 1970s (Finn E. Kydland and Carlos E. J. M. Zarazaga, 2002); in accounting for the 1929-39 Canadian depression (Pedro S. Amaral and James C. MacGee, 2002); and in accounting for the 35 percent trend-corrected decline in output in the United States in the 1930-33 period (Ohanian, 2001). I now show that the productivity factor is the major determinant of the behavior of the postwar Japanese economy.

\section{A. Japan in the Postwar Period}

The accounting for changes in output per working-age person is shown in Table 5. The motivation for breaking up the time period this way is that within subperiods, productivity growth is relatively constant, and between adjacent subperiods, productivity growth is very different. Given the behavior of the productivity factor, the nonconstant growth behavior of the capital and labor factors conforms with the predictions of theory.

\section{Table 5}

\section{Accounting for Japanese Growth per Person Aged 20-69}

\begin{tabular}{cccccc}
\hline \multirow{2}{*}{ Period } & Growth rate & \multicolumn{4}{c}{ Factors } \\
\cline { 3 - 6 } & & Trend & Productivity & Capital & Labor \\
& & growth & & & \\
\hline $1960-1973$ & $7.2 \%$ & $2.0 \%$ & $4.5 \%$ & $2.3 \%$ & $-1.5 \%$ \\
$1973-1983$ & $2.2 \%$ & $2.0 \%$ & $-1.2 \%$ & $2.1 \%$ & $-0.7 \%$ \\
$1983-1991$ & $3.6 \%$ & $2.0 \%$ & $1.7 \%$ & $0.2 \%$ & $-0.4 \%$ \\
$1991-2000$ & $0.5 \%$ & $2.0 \%$ & $-1.7 \%$ & $1.4 \%$ & $-1.3 \%$ \\
\hline
\end{tabular}

Source: Hayashi and Prescott (2002). 
The Japanese economy underwent remarkable changes in the $1960-2000$ period. Figure 3 plots GDP per person aged 20-69 for Japan. As the figure shows, Japan experienced a growth miracle in 1960-72, a period when its country-specific productivity factor increased by 71 percent. Growth was slightly above trend in the $1973-83$ period, with the positive capital contribution offset by the negative productivity contribution. The productivity factor again contributed positively to growth in 1983-91, a period characterized by rapid but not spectacular growth.

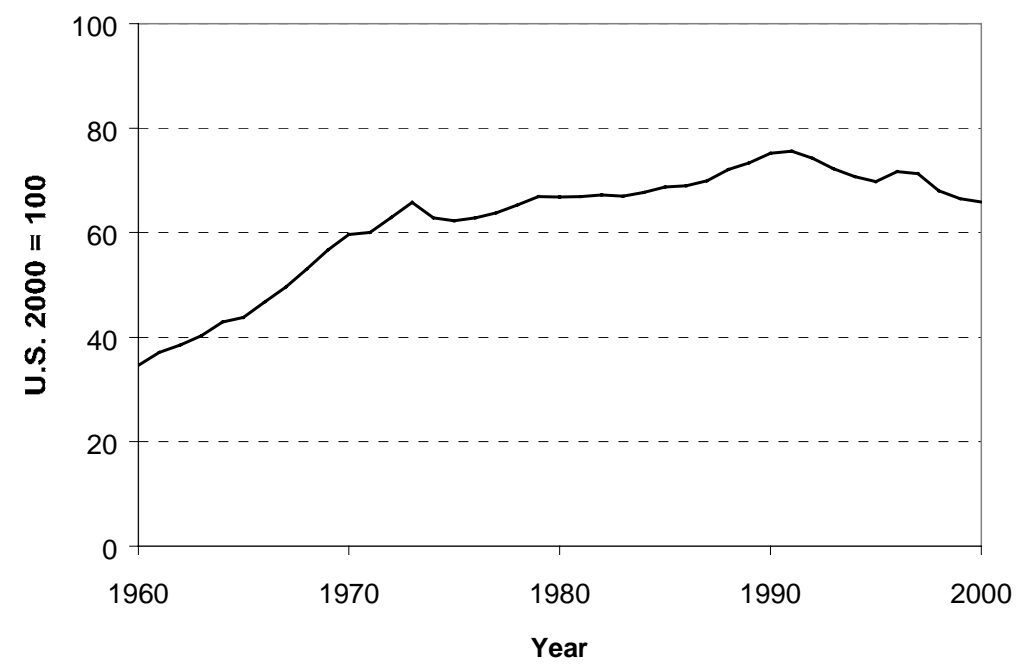

Figure 3: Detrended Japanese GNP per Person Aged 20-69

The Japanese economy lost ground relative to trend in the 1991-2000 period. The problem was the country-specific productivity factor, which fell 17 percent in the 10 -year period from 1991 to 2000. The growth in GDP per person aged 20-69 was 7.2 percent a year in 196072, which is miraculous. In the 1960s, Japanese living standards doubled, which requires 35 years for a country growing at the trend rate. As theory predicts, there was capital deepening and declining labor input as the economy reduced the distance it was below its constantly changing 
constant growth path. In 1973-83, productivity growth plunged. The growth in this period was mainly due to an increase in the capital factor.

\section{B. How Does the Theory Do in the Earlier Period?}

An estimate for each parameter can be obtained using only the observations for a single year and the consumption for the subsequent year. If the parameter estimates stay relatively constant over time and display no trend, the predicted path of the economy will be close to the actual path. In making these predictions, productivity, population, and the tax variables are taken as exogenous. For the Japanese economy, these parameters are nearly constant from 1970 to 2000, as can be seen in Table $6 .^{12}$

\section{Table 6}

Average Parameter Estimates for Japan

\begin{tabular}{ccccc} 
period & $\delta$ & $\theta$ & $\beta$ & $\alpha$ \\
\hline $1960-69$ & 0.131 & 0.385 & 0.933 & 1.781 \\
$1970-79$ & 0.101 & 0.351 & 0.971 & 2.321 \\
$1980-89$ & 0.094 & 0.354 & 0.971 & 2.277 \\
$1990-99$ & 0.096 & 0.363 & 0.967 & 2.424
\end{tabular}

Parameter constancy, however, does not hold for the 1960s. In the 1960s, the value of $\beta$ was lower than it was after 1970, and, more important, the disutility of work as measured by $\alpha$ increased steadily over the decade. Perhaps, for the extremely long workweeks of the 1960s, there were decreasing returns to longer workweeks. If so, a better modeling of the employmenthours decision is needed. ${ }^{13}$ 
Given the importance of the productivity factor, the mapping between policies and the productivity factor is important for understanding how to create prosperity. I will discuss three policies that empirically appear to affect productivity.

\section{Trading Clubs and Productivity}

The first is the policy of setting up what I will call a trading club. As seen in Table 1, five Western European countries had a large increase in their country-specific productivity factor beginning in the late 1950s and continuing into the 1990s. These countries-Belgium, France, Germany, Italy, and Netherlands-are prosperous relative to their trend-corrected levels in the 1913-38 period. What policy change accounts for this prosperity? What these countries have in common is that, along with Luxembourg, they are the original European Union countries that signed the Treaty of Rome in 1957. This fact, along with some theoretical reasoning, suggests that establishing this trading arrangement was crucial to the dramatic growth in productivity.

I define a trading club as a set of states with a considerable degree of sovereignty. The states agree not to subsidize their producers who either export goods or produce goods that compete with foreign imports. With such a policy game, inefficient industries that seek the protection of their state cannot be granted this protection without violating the club's agreement. Export industries face elastic demand, and jobs are gained, not lost, when production efficiency is increased. In these cases, there is no opposition to more efficient production. In addition, a trading club arrangement is sustainable, because efficient exporters will oppose violating the rules governing trade when inefficient producers seek protection.

Formal membership of neighboring states is not necessary for a country to be de facto subject to the rules of the club. This may account for the growth in trend-corrected productivity in states neighboring the original European Union members. In some cases, the productivity 
growth occurred well before the state joined this union. In other cases, such as Greece, Ireland, and Portugal, much of the growth in country-specific productivity occurred after the state joined the European Union.

The European Union is not the only important and successful trading club. After the U.S. civil war (Maddison, 2001, Table E7, p. 351), GDP per hour was 13 percent higher in the United Kingdom than in the United States. By 1913, the United States was 16 percent more productive, and by 1929, the United States 30 percent more productive. In the 1870-1929 period, the United States was a trading club with free movement of goods and people between states. Perhaps this is why the United States not only caught up to the United Kingdom in terms of productivity in this period, but surged far ahead of it.

\section{Financial Systems and Productivity}

Another policy associated with poor productivity performance is centralized allocation of savings to investments. As shown by Bergoeing et al. (2002), Chile and Mexico had financial crises and large declines in output in the early 1980s. Chile reformed its financial system and adopted a sound market mechanism to allocate savings to investment. Chile's productivity and output quickly recovered. Mexico did not reform its financial system, and productivity and output did not recover. Mexico is still depressed by 30 percent relative to its level in 1982, the year its depression began.

The candidate mechanism by which centralized financial systems adversely affect productivity is as follows. Inefficient producers are subsidized in order to preserve jobs. This has the perverse effect of lowering productivity and decreasing overall employment in the economy. Japan is another depressed country with a highly centralized financial system controlled by the 
state. Perhaps this accounts for the 17 percent decline in its productivity factor in the 1991-2000 period.

\section{E. Competition and Productivity}

Production organizations are complex entities with behavior that is the outcome of a complicated dynamic game. There is no guarantee that the equilibrium outcome of such a game will be characterized by efficient production. Martin Neil Baily and Solow (2001) report from productivity studies using firm-based studies that when faced with international competition, industry productivity increases to best practice levels. Jose E. Galdon-Sanchez and James A. Schmitz, Jr. (forthcoming) find that North American iron mines doubled their productivity in the early 1980s by simply changing work practices. This change occurred because of excess capacity in the industry at that time. Mines had to either increase productivity or be shut down.

Thomas J. Holmes and Schmitz (2001) present strong evidence that competition from railroads led to increases in the efficiency of water transportation in the U.S. post-Civil War period. If they are correct and productivity depends upon the nature of the competitive environment, railroads were important in U.S. economic development in the 1870-90 period when the dominant means of transportation shifted from the waterways to the railways. Similarly, the interstate highway system was important in U.S. economic development in the 1960-90 period when the dominant means of transportation shifted from railways to highways.

\section{Conclusions}

Depressions are not a thing of the past, even for rich industrial countries. Switzerland is currently depressed 30 percent relative to its trend-corrected 1970 level, and Japan is currently depressed 20 percent relative to its 1991 level and continues to become more depressed. On the prosperity side, Ireland is 60 percent more prosperous than in 1970, correcting for trend growth. 
Growth theory is a powerful tool for studying depression and prosperity. French, Japanese, and U.S. workers all have similar preferences. The French are not better at enjoying leisure. The Japanese are not compulsive savers. In this lecture, I use this theory to develop a system of accounting for differences in output per working-age person. One factor is the exogenous level of technology. It is common across countries and grows smoothly over time. Another factor is the capital factor, which depends upon how capital is taxed and the nature of capital market distortions. This factor turned out not to be very important in accounting for differences across countries and time.

The labor factor, however, turned out to be important. The differences in the consumption and labor tax rates in France and the United States account for virtually all of the 30 percent difference in the labor input per working-age person. The welfare gains associated with France reducing its intratemporal tax wedge are large. Is the low labor supply in Germany, Italy, and Spain also due to a tax system that makes consumption expensive in terms of leisure? Other labor policies also have large macro effects as evidenced by the Great U.K. Depression that began in 1920 and continued for nearly 20 years and the interwar German depression.

The final factor, productivity, is the most important one. It accounts for the behavior of the Japanese economy in 1960-2000, a period during which both a growth miracle and a depression occurred. It accounts for much of the current differences in income across the OECD countries today and changes in relative incomes of these countries over time. In this lecture I discuss three polices that empirically appear to affect the productivity factor. Trading clubs, sound competitive mechanism for the allocation of saving to investment, and competitive arrangements all appear to foster production efficiency. More industry studies with careful micro measurement, along with 
better theory, hopefully, will provide a better understanding of how policy determines productivity and this understanding will lead to better policy. 


\section{Notes}

${ }^{1}$ In 1934, Carl Warburton published a table that contained gross national product for the United States with a breakdown between consumption and investment (Ruggles,1983, p. 17).

${ }^{2}$ The findings are consistent with those of James J. Heckman and Thomas E. McCurdy (1980) when they estimate labor supply for females taking into consideration the employment rate margin.

${ }^{3}$ See Richard Rogerson (1988), Gary D. Hansen (1985), and Andreas Hornstein and Prescott (1993).

${ }^{4}$ Peter J. Klenow and Andres Rodriguez-Clare (1997) use this capital factor in their accounting for international income differences.

${ }^{5}$ For a detailed examination for the United States in the postwar period, see Ellen R. McGrattan and Prescott (2001). All of the factors that arise from the Dale Jorgenson and Robert E. Hall (1969) rental price of capital are incorporated in that analysis.

${ }^{6}$ See McGrattan and Ohanian (1999) and Jonas D. M. Fisher and Hornstein (2002). They find that public expenditures for military purposes are largely offset by reductions in private consumption, as theory predicts.

${ }^{7}$ Capital stock data for Canada are available, but that country clearly used a different concept of capital when reporting to the OECD, because the number reported is near $1 \mathrm{GNP}$. The Japanese capital stock figure is obtained from the Japanese SNA and is for 1998. Not until 1998 did the Japanese capital/output ratio approach its constant growth value. 
${ }^{8}$ The source of the data used for the calculations of the tax rates is the United Nations (2000). These tax rates are the average for 1993-95, which are the latest years for which the needed data are available.

${ }^{9}$ See McGrattan and Prescott $(2000,2001)$ for more on taxes.

${ }^{10}$ I used the U.S. IRS (1999) Individual Income Returns 1997, Table 3.6, to obtain these fractions.

${ }^{11}$ Not all accept these findings. In particular Robert E. Lucas, Jr. (2002) concludes that country-specific productivity factors are second-order in understanding large international income differences, as do Larry E. Jones and Rodolfo E. Manuelli (1997).

${ }^{12}$ The capital share parameter in the production function is greater than the typical 0.30 number for other countries because of the high value of land in Japan relative to GNP.

${ }^{13}$ Hayashi and Prescott (2002) found that the workweek in the late 1980s was longer than what the Japanese people wanted. The labor input fell when it was reduced from 44 to 40 hours a week to be consistent with people's preferences in the 1989-92 period. Their representation of preferences is a local approximation. 


\section{References}

Amaral, Pedro S. and MacGee, James C. "The Great Depression in Canada and the United States: A Neoclassical Perspective." Review of Economic Dynamics, January 2002, 5(1), pp. $45-72$.

Baily, Martin Neil and Robert M. Solow. "International Productivity Comparisons Built from the Firm Level." Journal of Economic Perspectives, Summer 2001, 15(3), pp. 151-72.

Beaudry, Paul and Portier, Franck. "The French Depression in the 1930s." Review of Economic Dynamics, January 2002, 5(1), pp. 73-99.

Bergoeing, Raphael; Kehoe, Patrick J.; Kehoe, Timothy J. and Soto, Raimundo. "A Decade Lost and Found: Mexico and Chile in the 1980s." Review of Economic Dynamics, January 2002, 5(1), pp. 166-205.

Cole, Harold L. and Ohanian, Lee E. "The Great Depression in the United States from a Neoclassical Perspective." Federal Reserve Bank of Minneapolis Quarterly Review, Winter 1999, 23(1), pp. 2-24.

. "New Deal Policies and the Persistence of the Great Depression: A General Equilibrium Analysis." Minneapolis Federal Reserve Bank Working Paper, Number 597, revised May 2001.

. "The Great U.K. Depression: A Puzzle and Possible Resolution.” Review of Economic Dynamics, January 2002, 5(1), pp. 19-44.

Clark, Colin. National Income and Outlay. London: Macmillan, 1937.

Fisher, Jonas D. M. and Hornstein, Andreas. "The Role of Real Wages, Productivity, and Fiscal Policy in Germany's Great Depression 1928-1937." Review of Economic Dynamics, January 2002, 5(1), pp. 100-27.

Galdon-Sanchez, Jose E. and Schmitz, James A., Jr. "Competitive Pressure and Labor Productivity: World Iron-Ore Markets in the 1980's." American Economic Review, forthcoming.

Gollin, Douglas. "Getting Income Shares Right.” Journal of Political Economy, forthcoming. 
Hall, Robert E. and Jones, Charles I. "Why Do Some Countries Produce So Much More Output per Worker than Others?" Quarterly Journal of Economics, February 1999, 114(1), pp. 83-116.

Hall, Robert E. and Jorgenson, Dale. "Tax Policy and Investment Behavior: Reply and Further Results.” American Economic Review, June 1969, 59(3), pp. 388-401.

Hansen, Gary D. "Indivisible Labor and the Business Cycle." Journal of Monetary Economics, November 1985, 16(3), pp. 309-27.

Hayashi, Fumio and Prescott, Edward C. "The 1990s in Japan: A Lost Decade." Review of Economic Dynamics, January 2002, 5(1), pp. 206-35.

Heckman, James J. and McCurdy, Thomas E. "A Life Cycle Model of Female Labour Supply." Review of Economic Studies, 1980, 47(1), pp. 47-74.

Holmes, Thomas J. and Schmitz, James A., Jr. "Competition at Work: Railroads vs. Monopoly in the U.S. Shipping Industry.” Federal Reserve Bank of Minneapolis Quarterly Review, Spring 2001, 25(2), pp. 3-29.

Hornstein, Andreas and Prescott, Edward C. "The Firm and the Plant in General Equilibrium Theory," in R. Becker, M. Boldrin, R. Jones, and W. Thomson, eds., General Equilibrium, Growth, and Trade. Vol. 2. The Legacy of Lionel McKenzie, Economic Theory, Econometrics, and Mathematical Economics Series. San Diego: Academic Press, 1993, pp. 393-410.

Jones, Larry E. and Manuelli, Rodolfo E. “The Sources of Growth.” Journal of Economic Dynamics and Control, January 1997, 21(1), pp. 75-114.

Kehoe, Timothy J. and Prescott, Edward C. "Great Depressions of the $20^{\text {th }}$ Century." Review of Economic Dynamics, January 2002, 5(1), pp. 1-18.

Kendrick, John W. "Productivity Trends; Capital and Labor." National Bureau of Economic Research Occasional Paper Series No. 53, 1956.

Klenow, Peter J. and Rodriguez-Clare, Andres. "The Neoclassical Revival in Growth Economics: Has it Gone Too Far?” in B. Bernanke and J. Rotemberg, eds. NBER Macroeconomics Annual 1997. Cambridge, MA: MIT Press, 1997, pp. 73-102. 
Kuznets, Simon S. Cyclical Fluctuations. New York: National Bureau of Economic Research, 1926.

- National Income and Capital Formation 1919-1935: A Preliminary Report. New York: National Bureau of Economic Research, 1937.

. National Income and Its Composition, 1919-1938. New York: National Bureau of Economic Research, Columbia University Press, 1941.

Kydland, Finn E. and Zarazaga, Carlos E. J. M. “Argentina's Lost Decade.” Review of Economic Dynamics, January 2002, 5(1), pp. 152-65.

Ljungqvist, Lars and Sargent, Thomas J. "The European Unemployment Dilemma.” Journal of Political Economy, June 1998, 106(3), pp. 514-50.

Lucas, Robert E., Jr. Lectures on Economic Growth. Cambridge: Harvard University Press, 2002.

Maddison, Angus. Monitoring the World Economy 1820-1992. Development Centre of the OECD, 1995.

. The World Economy: A Millennial Perspective. Development Centre of the OECD, 2001.

McGrattan, Ellen R. and Ohanian, Lee E. "The Macroeconomic Effects of Big Fiscal Shocks: The Case of World War II," Federal Reserve Bank of Minneapolis Working Paper No. 599, December 1999.

McGrattan, Ellen R. and Prescott, Edward C. "Is the Stock Market Overvalued?" Federal Reserve Bank of Minneapolis Quarterly Review, Fall 2000, 24(4), pp. 20-40.

- “Taxes, Regulations, and Asset Prices." Federal Reserve Bank of Minneapolis Working Paper No. 610, revised July 2001.

McKenzie, Lionel W. "The Classical Theorem on Existence of Competitive Equilibrium." Econometrica, June 1981, 49(4), pp. 819-41.

OECD, Flows and Stocks of Fixed Capital 1971-1996, Paris: OECD, 1997. 
- National Accounts of OECD Countries, Volume I : Main aggregates, CD-ROM on Beyond 20/20. Paris: OECD, January 2001.

Ohanian, Lee E. "Why Did Productivity Fall So Much During the Great Depression?" American Economic Review, May 2001, 91(2), pp. 34-38.

Rogerson, Richard. "Indivisible Labor, Lotteries, and Equilibrium.” Journal of Monetary Economics, January 1988, 21(1), pp. 3-16.

Ruggles, Richard. "The United States National Income Accounts, 1947-1977: Their Conceptual Basis and Evolution." in Murray F. Foss ed., The U.S. National Income and Products Accounts: Selected Topics. Chicago: University of Chicago Press, 1983, pp. 1-96.

Solow, Robert. M. "Technical Change and the Aggregate Production Function." Review of Economics and Statistics, August 1957, 39(3), pp. 312-20.

Stone, Richard. "Nobel Memorial Lecture 1984: The Accounts of Society." Journal of Applied Econometrics, January 1986, 1(1), pp. 5-28.

Stone, Richard; Champernowne, D. G. and Meade, J. E. "The Precision of National Income Estimates." Review of Economic Studies, 1942, 9(2), pp. 111-25.

United Nations. National Accounts Statistics: Main Aggregated and Detailed Tables, 19961997. New York: United Nations, 2000.

United States Internal Revenue Service. Individual Income Tax Returns-1997. Washington, DC: U.S. Government Printing Office, 1999. 